\title{
COVID-19 Media Coverage on Spanish Public TV
}

\author{
Eduardo Villena-Alarcón \\ Lidia Caballero-Galeote \\ University of Malaga (Spain)
}

The respiratory syndrome SARS-CoV-2 has affected over 100 countries during the last weeks. On March 11, 2020, the World Health Organization declared the COVID-19 outbreak a pandemic and since 31 December 2019, 201,315 deaths have been reported. The media has played a key role in providing information and making people aware of the situation during this emergency situation. This research seeks to examine the coronavirus media coverage on the Spanish public TV (TVE1). In order to achieve this goal, a content analysis based on the five stages of grief, an audience survey, and focus group interviews were conducted. The results have shown that coverage has undergone different phases. Accordingly, each of these stages has been perceived by the audience. Although both the audience and the experts appreciate the work of Spanish public television, the majority opinion is negative. In this regard, they state that it has not been impartial and there has been an excess of information. For researchers, these results provide important guidelines to increase the number of literature reviews by considering not only the news but also the audience and experts' perceptions.

Keywords: COVID-19, coverage, audience, perceptions, content analysis.

$\mathrm{O}$

n 11 March 2020, the World Health Organization (WHO) officially declared the outbreak of SARS-CoV-2 (commonly known as COVID-19 or coronavirus) a pandemic. This virus, which began in Wuhan in December 2019, expanded to touch nearly every place around the globe. In Spain, the first contagion was reported on 31 January and the first death on 13 February. By the end of April 2020 in Spain, the epidemic had resulted in more than twenty-one thousand deaths and more than 200,000 infected. 
However, in the face of a pandemic and the consequent fear and uncertainty generated, it is necessary to sensitize the population and provide simple, truthful and timely information, based on available scientific evidence on how to prepare, organize in front of it (Avila et al., 2009; Castro, Arcos, and Rodríguez, 2009; Ruiz, 2020). Media are an important source of health information for a majority of the people (Covello and Peters, 2002; Francescutti, 2010) and it is, therefore, possible that health information is consumed under conditions of high elaboration, because it is likely that people who are reading or watching a news piece are doing so out of interest.

A number of studies have shown that media is a powerful instrument that has been used to effect social change. The most common strategy for studying news coverage is to analyse how it has been structured, the perspective, and the formal and technical aspects. This is an interesting point because the media have the power to choose what content can be broadcasted and from what perspective. In this sense, the media influences the perceptions of the public. Content analysis is revealed as an indispensable tool in this respect (Matthes, 2012). This research documents several key contributions made to the fields of media coverage (Berry, Wharf-Higgins, and Naylor, 2007; Camacho, 2009; Washer, 2004). In media studies, there is much more literature on written press than on television, radio, or the Internet (Revuelta, 2006). However, different authors have studied the television media system (Campos-Freire, 2009; Díaz-Nosty, 2009, 2017; Meilán, 2010; Puentes, Campos, and Fernández, 2018). According to Reig (2010), the television media system in Spain is characterized by a progressively increasing concentration, which is no longer a novelty but a market dynamic. Television has a penetration of $85.4 \%$ in Spain, almost ten percentage points more than the Internet, according to the Marco General de los Medios en España (2020), published by the Asociación para la Investigación de Medios de Comunicación (AIMC) based on data from Estudio General de Medios (EGM). Daily consumption is 219.9 minutes with maximums around 2:00 p.m. and 10:00 p.m. Aside from the Mediaset and Atresmedia duopoly (García, 2013), regarding TVE, the accumulated audience has been detrimental since 2004, reaching 21.7\% in 2019. For a time now, the public media, especially television and regional radios, have been plunged into serious sustainability problems (Sotelo, 2014). To which must be added the crisis of the concept of public television (Roel and Lafuente, 2005) that has led to the redefinition of the concept and the restructuring of RTVE. The magnitude of coronavirus creates a news value for the international press as nearly 80 countries reported cases of COVID-19 and worldwide 2,982,647 known infected persons and 206,342 deaths were listed by The WHO (2020). This paper aims to analyze how the Spanish public broadcaster reported on the public health crisis generated by the COVID-19 pandemic. Additionally, we examined how the audience has perceived the information and what are the experts' opinions about the informative treatment. This paper is divided into three parts: First, it presents a literature review examines studies published about coverage and health information. Then, it describes the methodology of the study, and it analyses news coverage, audiences' perception, and the focus group data. Finally, the paper presents the main findings in conclusions. The key contributions of this 
paper are divided into three categories. First, it contributes to the growing literature on COVID-19, the second one is related to the perceptions of the public and experts and the last one is based on the recommendations about the coverage of future crisis.

\title{
LITERATURE REVIEW
}

Research on media coverage has a long tradition in academic literature. For decades, one of the most popular ideas in media literature is the idea that information should be relevant and accurate for its purpose, and complete and reliable for the issue (Artandi, 1973), especially on public health issues. However, Chomsky and Ramonet (2013) affirm that the unbiased information is a myth that corresponds to the collective imagination. As cited by O'Neill and Harcup (2009):

\begin{abstract}
A potential pandemic matches perfectly with almost all criteria for news value such as: unexpectedness (sudden outbreak) as well as consonance with expectations (a new pandemic was long predicted), intensity increase (growing number of patients and fatalities), negativity (chance of a catastrophe), relevance (actual risks involved), meaningfulness (fear of epidemic, personal risks), unambiguity (flu is well known), continuity (daily updates) and unpredictability (will it be a severe epidemic?)
\end{abstract}

Media interest in certain topics does not arise in isolation but is influenced by other sectors such as the political agenda (Sádaba and Rodríguez, 2007) In this sense, the agenda-setting and the framing are essential (Scheufele and Iyengar, 2012). The amount of media attention devoted to particular issues determines the degree of public concern for these issues (Behr and Iyengar, 1985). The media has a great influence on the audience (MacKuen, Coombs, and Britan, 1981). The media agenda determines citizens' political priorities and it has a very important impact on their perceptions. This is carried out thanks to the control of the determination of which news has an informative interest and how much space is devoted to its dissemination.

Furthermore, if the framing theory is effective in this case, the public's perception must be conditioned by the subjective reconstruction carried out by the media. Recent theoretical developments have revealed that media coverage can be considered as an effective way to curb the spread of COVID-19 (Zhou et al., 2020). However, some media coverage of COVID-19 has negatively influenced (Lyu et al., 2020; Zheng, Goh, and Wen, 2020).

The outbreak triggered massive media attention all over the world and during consecutive months the new flu will continue to be a front-page topic. In a world marked by infoxication, the value of the media falls, in Lippmann's terms (2003: 33 ), on the need to provide models that explain the content of current news to public opinion. Together with other major public or private agents, the media also contributes to the shaping of the public agenda (McCombs and Evatt, 1995). It brings certain issues to the forefront of current affairs and silencing or ignoring others (McCombs, 2006). Politicians, topics, and events are subject to a se- 
lection and interpretation process, which is continuously negotiated, discussed, and modified (Matthes, 2012). This generates greater concern on this issue in the public eye (Igartua, Muñiz, and Otero, 2006) shaping the social reality of the viewer (McCombs and Shaw, 1972). Framing news information means emphasizing the relevance of certain aspects of a topic and, therefore, involves choosing one or several alternatives to focus on a certain social event (Vreese, 2003).

The media build an information pseudo-development (Rodríguez, 2011) through which information is transmitted to citizens. How news is presented plays an important role in opinion formation (Cacciatore, Scheufele, and Iyengar, 2016). How information is interpreted depends on how it is contextualized and framed.

It is important to identify television with a meaning creator instrument (Behr and Iyengar, 1985; Iyengar and Kinder, 1987; Rodríguez, 2011). In addition, television is the main channel through which a large proportion of the population is informed. Broadcasting quality information on public television (Caffarel, 2005) is not an easy task. Even more difficult if the new news programs were built on their audience's new habits and routines. Taking into account that television audiences have changed and with them the way of presenting information (Mateos-Pérez, 2009), the problem is greater. This has led to different formal proposals that contributed to bringing information closer to entertainment, something that has also affected content. Although the variety of new genres of information would improve the quality of the information, this has caused an audience drain. In the Spanish case, the profile of the young viewer who is ceasing to watch television (López, González, and Medina, 2011) responds to an individual between 18 and 25 years old, with studies, who does not consider himself a potential audience of current television programming. The appearance of new video on demand (VOD) platforms has allowed the viewer to skip the dictates of the grill and watch the content on demand has directly led to a leak in the audience of the live show (Neira, 2018).

According to the recent Digital News Report 2019 (Newman et al., 2019), Spaniards (72\%) express a clear preference for TV. The wide penetration of television has made it a reference for entertainment and, above all, for information due to its credibility and immediacy. 50\% of the population that watches television uses it as the main source of information (Berganza, 2008; Marín, 2008). In this respect, according to Camacho (2009), the mass media have responded to this social interest by considerably increasing the amount of information related to health. As can be seen in Table 1 research on media coverage of health crises is spread globally in the major academic papers and reviews. Content analysis has been the methodology used in all cases presented below. 
Table 1. Literature review about media coverage

\begin{tabular}{|c|c|c|c|c|}
\hline Theme & Author & Year & Media & Finding \\
\hline SARS & Washer & 2004 & Newspaper & Media's coverage reveals the risk posed by SARS. \\
\hline $\begin{array}{l}\text { Health } \\
\text { information }\end{array}$ & Berry et al. & 2007 & $\begin{array}{l}\text { Print, radio, } \\
\text { Tv and } \\
\text { Internet }\end{array}$ & $\begin{array}{l}\text { Health topics were more often discussed in terms of } \\
\text { risk, by credible sources using strong language. }\end{array}$ \\
\hline Influenza A & Camacho & 2009 & Newspaper & $\begin{array}{l}\text { Newspapers offered too alarming and sensationalist } \\
\text { information. }\end{array}$ \\
\hline Influenza A & $\begin{array}{l}\text { Holland \& } \\
\text { Blood }\end{array}$ & 2010 & Newspaper & $\begin{array}{l}\text { Official statements represented in the media } \\
\text { combined to create the impression of a virus that } \\
\text { was spreading beyond the control of the health } \\
\text { authorities. }\end{array}$ \\
\hline Influenza A & $\begin{array}{l}\text { Hilton \& } \\
\text { Hunt }\end{array}$ & 2010 & Newspaper & $\begin{array}{l}\text { "The news media's role as a disseminator } \\
\text { of scientific information is particularly important in } \\
\text { areas of risk perception." }\end{array}$ \\
\hline influenza A & $\begin{array}{l}\text { Cevallos \& } \\
\text { Massarani }\end{array}$ & 2011 & TV & Scientists were little consulted as sources. \\
\hline Influenza A & $\begin{array}{l}\text { Da Silva } \\
\text { Medeiros \& } \\
\text { Massarani }\end{array}$ & 2011 & TV & $\begin{array}{l}\text { The coverage has contributed to the "pandemic of } \\
\text { panic" dissemination. }\end{array}$ \\
\hline Avian flu & Shih et al. & 2011 & Newspaper & $\begin{array}{l}\text { Government, scientists and the World Health } \\
\text { Organization were the most prominent sources in } \\
\text { avian flu coverage. }\end{array}$ \\
\hline Influenza A & Fogarty & 2011 & TV & $\begin{array}{l}\text { Commentary on changes in the pandemic alert } \\
\text { level were seldom contextualised to assist viewers in } \\
\text { understanding personal relevance. }\end{array}$ \\
\hline $\begin{array}{l}\text { Health } \\
\text { information }\end{array}$ & Francescutti & 2013 & TV & $\begin{array}{l}\text { TV news shared a much lower number of health news } \\
\text { than those devoted to sports, politics or events. }\end{array}$ \\
\hline Ébola & Ihekweazu & 2017 & TV & $\begin{array}{l}\text { Relationship between location and sensationalism in } \\
\text { health news coverage in television nightly news. }\end{array}$ \\
\hline
\end{tabular}

Source: The authors.

In 2013, Francescutti (2013) identified the usual topics on Spanish TV in relation to the health news. Among others, it could be found: health policies (15.9\%), management of the Spanish sanitary system (13.9\%), health habits (12.3\%), and foreign health policy (10.5\%).

The daily news broadcast is, from a historical perspective, one of the highest-rated programs on television (Peralta, 2012). In the Spanish case, 39\% of respondents choose TVE news to be informed. With $6.92 \%$ confidence, in terms of share, the only public television in Spain is the third or fourth choice among all television networks and its online version is visited by $10 \%$. In any case, the public television model must be rethought, as a competitive and 
open system, with the aim of ensuring a communication system for the public (Moragas and Prado, 2001). Studies on media coverage are indispensable for the formation of public opinion and democratic, social, and cultural needs (Perales, 2003).

In a world where the global population is rising, the public health crises generate a substantial need for information. In this context, citizens look to the media to explain the facts and understand the consequences (Perse, 2001), especially if it affects internationally. The media in Spain have tracked the COVID-19 pandemic, just as they did it with the 2008 crisis (Gil, 2017), SARS, influenza A or Ebola. Several papers appeared documenting the coverage of avian influenza and SARS. They focused on the worst scenarios and offered a very intensive and at times, emotionally charged language (Berry, Wharf-Higgins, and Naylor, 2007; Washer, 2004). In relation to the language of the media, the coverage of the health crisis generally uses military metaphors (Chiang and Duann, 2007; Larson, Nerlich, and Wallis, 2005; Martín, 2007; Williams, 2009).

Researchers from around the globe have also shown an interest in public health issues and their media coverage (Vasterman and Ruigrok, 2013). Current research on news coverage was focused on content analysis (Balabanić and Benković, 2014; Dudo, Dahlstrom, and Brossard, 2007; González and Portilla, 2014; Joye, 2010; Vasterman and Ruigrok, 2013). A common technique is to content analysis because it reveals keywords, expressions, stereotyped images, sources, and interpretive key phrases contained in the text (Entman, 1993). For instance, some authors have driven the further development of the construction of messages (Berry, Wharf-Higgins, and Naylor, 2007; Atlani et al., 2015). A large number of existing studies in the broader literature have examined the discourse of news broadcast on television, the structure (Joye, 2010), the frames (Beaudoin, 2007), and the critical discourses (Chiang and Duann, 2007). To examine the direct and interactive influence of certain variables with the way of informing and public knowledge, current research is focused on surveys (Hu and Zhang, 2014; Ho, 2012). Another instrument used to analyse news coverage can be the interview. As Wong and Sam (2010) affirm, the interview provides information about the sources, needs, and preferences of the audience. Although there are many studies, the research about the coronavirus remains limited. One of the main weaknesses of this study is its territorial nature. The study is based on Spanish public television although its use can be adapted to other countries. Also, the study analyzes and compares various aspects of television news coverage and treatment; without dealing with other media or other formats. Nevertheless, there are still some interesting and relevant problems to be addressed. More specific research questions will be introduced and investigated in this paper.

- RQ1. What has been the communicative approach to COVID-19 crisis?

- RQ2. What has been the public's perspective on news coverage?

- RQ3. What has been the experts' perspective on news coverage? 


\section{METHODOLOGY}

This research is divided into three different sections. A content analysis, a survey, and two focus groups were carried out. The main aim of this study was to analyze the TVE1 news coverage of COVID-19. The content analysis as a systematic approach was chosen due to the fact that all studies consulted used this analysis to examine media coverage. This tool is based on the analysis and interpretation of documented sources. Data were collected from the website Verba (Graph 1) from 2014 until April 14th, 2020. This open-source website allows us to examine the content of the news through the subtitles from 2014 until now. The web browser supports different Boolean operators. In order to address the aim of this study the search queries were focuses on COVID-19, Coronavirus, and Pandemic. This application provides the subtitles with the start-time, end-time, program id, and date.

\section{Graph 1. Website Verba}

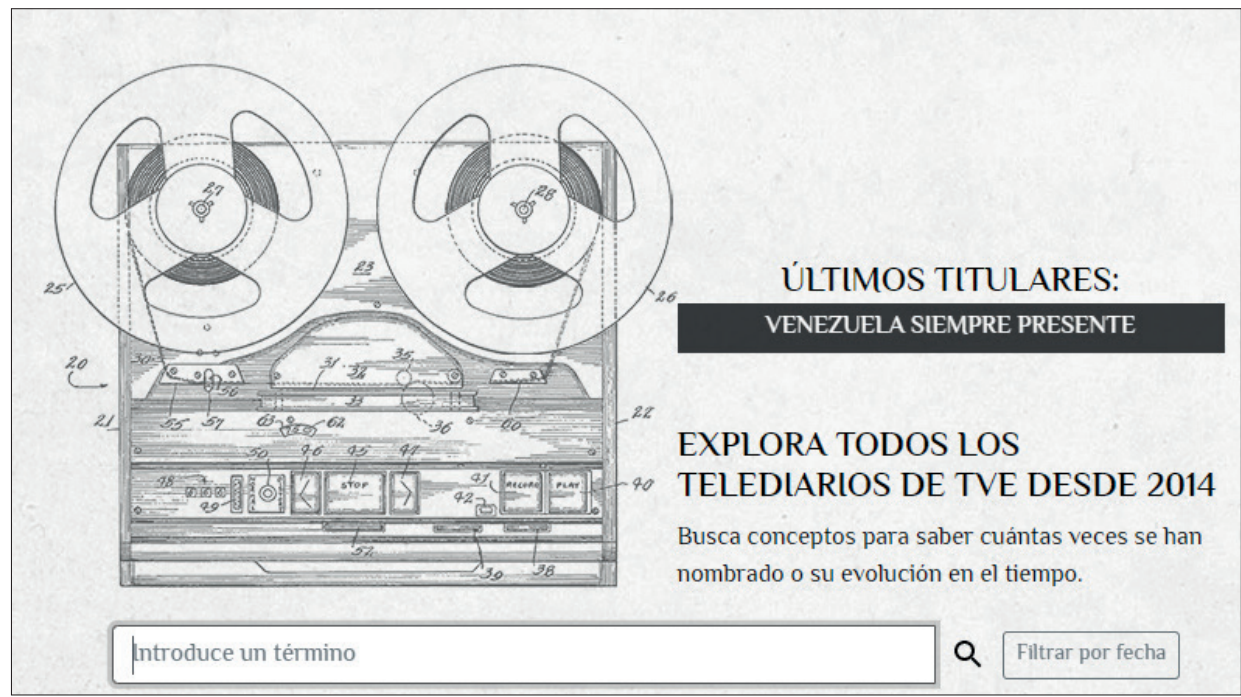

Source: VERBA.

The second goal was to examine how the public has perceived COVID-19. A survey of 54 people has been carried out for this purpose. Respondents were selected by the proportional quota sampling. This technique is a non-probability sampling technique where the sample collected has the same proportion of individuals as the entire population with respect to the phenomenon being targeted. In this sense, a distribution has been made according to age, gender, level of income, and occupation. Once the participants were selected, the questionnaire was sent via WhatsApp. Data collection was performed during the lockdown period (from April 10 to April 15). The final survey was prepared using open questions. The questionnaire was divided into three sections. The first one was in relation to the overall perception of COVID-19 coverage. The second was about 
110 the role of the media and the third about improvements. Responses were coded using NVivo Pro qualitative analysis package. In relation to the focus group interviews, 13 experts were selected to complete the study. In this sense, this tool is a useful method to investigate and discover how agents feel about an issue and the reason why they hold certain opinions.

\section{FINDINGS}

A total of 2620 news subtitles were analyzed. The word 'coronavirus' was introduced 2657 times. In January 2020, no mention was recorded, in February there were 613 mentions, in March 1411 and up to 14 April; 432.Content analysis has revealed that the first registered mention of the coronavirus in the TVE1 news was on 1 May 2014. The news talked about a virus that caused respiratory failure.

In Saudi Arabia, the health alarm is growing due to the death of 107 people from the socalled coronavirus, which causes respiratory failure with high mortality rates.

The following mentions were made during the same month as can be seen in the following table:

Table 2. Mentions about the coronavirus (2014)

\begin{tabular}{l|l|l|l}
\hline May & 6 & 2014 & $\begin{array}{l}\text { More than } 700 \text { people worldwide have been infected with the Middle East } \\
\text { Respiratory Syndrome, known as the coronavirus. More than 200 people are } \\
\text { known to have died. }\end{array}$ \\
\hline May & 6 & 2014 & It's called a coronavirus because of the crown that surrounds it. \\
\hline May & 6 & 2014 & The presence of the coronavirus in humans is common. \\
\hline May & 6 & 2014 & Coronavirus originating in the Arabian Peninsula causes pneumonia. \\
\hline
\end{tabular}

Source: Authors from Verba.

It was not until 2015 that the coronavirus was again covered on the TVE1 news. It was June 7, 2015; a 75-year-old man had died of the coronavirus.

Table 3. Mentions about the coronavirus (2015)

\begin{tabular}{l|l|l|l}
\hline May & 13 & 2015 & $\begin{array}{l}\text { In South Korea, thousands of officials have undergone medical checks for possible } \\
\text { coronavirus infections. }\end{array}$ \\
\hline May & 16 & 2015 & The first victim in Europe of the coronavirus. \\
\hline May & 16 & 2015 & $\begin{array}{l}\text { First death in Europe in the current outbreak of MERS coronavirus or Middle East } \\
\text { Respiratory Syndrome. }\end{array}$ \\
\hline
\end{tabular}


The January 17 was the first time that COVID-19 had coverage in the TVE1 news. The subtitles indicated:

Health officials insist that the origin is a new coronavirus different from that of the deadly Asian bird flu of 2003; it has been found in some trash at the city's seafood market, and once the market has been closed, no more cases could be found.

On the evening news $(01 / 17 / 2020)$, official health sources confirmed a new case in Thailand and another in Japan. The World Health Organization had issued a warning about the health threat of a new coronavirus discovered in China that had already caused the death of two people. Although they insisted that this coronavirus would not have the same impact as that of the bird flu that killed more than 700 people almost two decades ago.

The January 21, the fear of contagion has been increased after it was confirmed that this coronavirus is transmitted from human to human. This day on the evening news the first case in the United States was confirmed.

January 22:

The WHO will decide today whether or not to declare an international emergency for the Chinese coronavirus, which has already caused nine deaths and more than 470 cases.

Masks in Beijing to prevent the infection caused by the coronavirus. It has already killed 17 people in China.

On January 23:

The coronavirus detected in China could have reached Europe. A woman has been admitted to Bari University Hospital in Italy for possible infection of coronavirus.

In the following two days, several events took place. On the one hand, Spain announced two possible cases of infected people, Wuhan was building a hospital, in Hubei masks were being produced non-stop and France confirmed its first two positives. The virus had reached Europe. On January 25, the TV news announced that Spain was prepared for the coronavirus. It's worth mentioning that this was the first time that news talked about the crisis. While the possible origin of this virus and its economic repercussions were being discussed, the news in Spain focused on a CSIC team that had already managed to create vaccines for other coronaviruses.

On January 28, it was stated with considerable certainty that this coronavirus came from bats. The first infection in Germany is confirmed. The coronavirus continues to advance... leaving 170 dead and over 7,700 infected. The number of headlines about the coronavirus increased from three $(01 / 17 / 2020)$ to an average of $25(01 / 29 / 2020)$ to $30(01 / 30 / 2020)$ news per day. On January 30th, the World Health Organization decreed an international alert for the coronavirus. 
On February 1, the first coronavirus patient was registered in Spain (La Gomera). He was a German tourist. A day later, Italy had two cases of coronavirus and the first death occurred outside China. The World Health Organization warned about too much information about COVID-19. The Mobile World Congress may not take place. Experts affirmed:

You should be more afraid of the flu than the coronavirus. In Spain, everything is under control.

As Wuhan would have opened a new hospital built in ten days, the news talked about the amount of false news and the bat soup that may have caused the virus. According to an expert from the University of Barcelona, the coronavirus could live for a couple of days on a surface and become infected not only through respiratory secretions but also through feces (02/05/2020). The Mobile World Congress was being cancelled over coronavirus concerns while in South Korea, 6,000 couples from 64 countries were getting married (02/07/2020).

As we have seen in the preceding paragraphs, TVE news were focused on showing calm. Scientists explained that the flu was even more dangerous, data about new vaccines, and well prepared teams to act when necessary. However, news in relation to other countries was increasing its harshness. From this moment on, the content analysis revealed three clearly differentiated categories and three sub-categories. The first one was in relation to the origin of the virus, the second about Spain, the third about the global impact of the virus. The three sub-categories were economy, sport, and weather. In relation to the origin of the virus, numerous subtitles appeared. Until March 1 it was stated that the pangoli would be responsible for the transmission of the virus to humans and since March 1 there are no mentions of its origin, although scientists around the world are working on it. The most relevant subtitles could be found in Table 4 .

Table 4. Mentions about the origin

\begin{tabular}{l|l|l|l}
\hline 7 & February & 2020 & $\begin{array}{l}\text { This animal, a pangolin, could be the transmitter of the coronavirus. } \\
\text { This animal is a pangolin, a mammal that a Chinese scientific identifies as } \\
\text { the possible vehicle for transmitting the coronavirus from bats to humans. } \\
\text { Chinese researchers believe that this animal, the pangolin, a delicacy in } \\
\text { China, may be the transmitter of the coronavirus. }\end{array}$ \\
\hline 1 & March 2020 & $\begin{array}{l}\text { The exact origin of COVID-19 is unknown at this time, although scientists } \\
\text { around the world are working to find out where it came from so that a } \\
\text { vaccine can be developed. }\end{array}$ \\
\hline
\end{tabular}

Source: Authors from Verba.

In relation to the coverage of the virus in Spain, the analysis of the contents reveals that the country would have gone through different stages. These stages could be compared with the stages of grieving and adjustment caused by death. 
As indicated by Rando (2015) and Gamo and Pazos (2009), there are different phases, the first moments, a clash with reality, and a third phase in which the individual overlaps and tries to get back to living of 'normal' life. This is what happens in this research. The denial, an initial step, is a natural defense mechanism. This reality could not be happening to us. At each of these stages, the concern and the fear increase, and the energy go down. Exactly the same thing happened with the number of news items. This can be seen in Graph 2. If we observe the Table 5 we are able to examine that at the beginning of the pandemic, the number of news about the coronavirus at the international level was much higher than the news dedicated to Spain.

\section{Graph 2. Comparison between national and international news during the different steps}

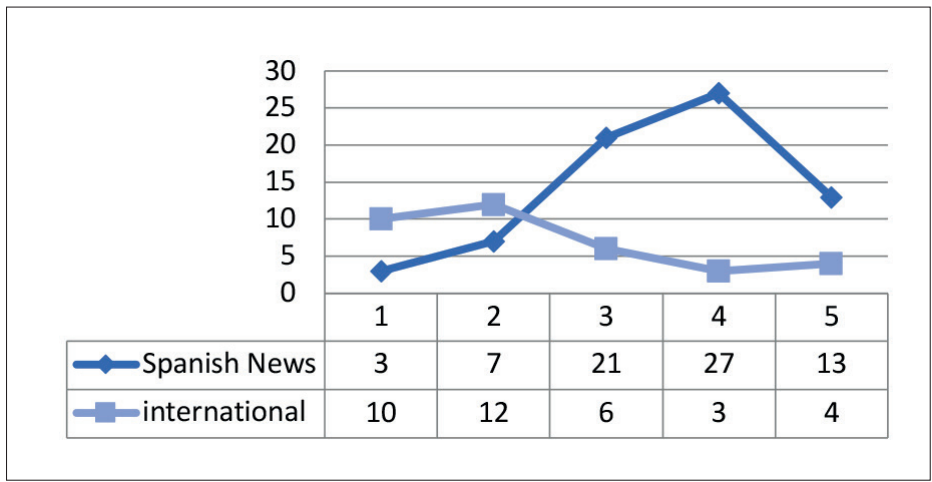

Source: The authors.

Table 5. Coronavirus coverage

\begin{tabular}{l|l|l|l|l} 
Date & Minutes & News Item & $\begin{array}{l}\text { Coronavirus news subtitles } \\
\text { per news program }\end{array}$ & $\%$ \\
\hline $01 / 17 / 2020$ & 46 & 27 & 3 & 11.11 \\
\hline $02 / 07 / 2020$ & 45 & 24 & 7 & 29.17 \\
\hline $02 / 27 / 2020$ & 46 & 25 & 21 & 84 \\
\hline $03 / 15 / 2020$ & 46 & 27 & 27 & 100 \\
\hline $04 / 11 / 2020$ & 47 & 24 & 13 & 54.17 \\
\hline
\end{tabular}

Source: The authors.

\section{Initial Stage (Spain)}

- In Spain, the only confirmed case of coronavirus remains hospitalized without symptoms. 
- $\quad$ Spain adds its second case of coronavirus and from Health insists on launching a message of calm.

- The patient hospitalized for coronavirus in La Gomera has tested negative for the first time.

- The German citizen hospitalized on La Gomera with coronavirus was negative in the last test and was discharged this morning.

- Here in Spain, there are no cases of coronavirus.

- In Spain, there is no coronavirus, the disease is not being transmitted and there are no cases at present.

The second stage is for this study the stage of concern. Once people start to live in the new reality, concern might start to set in. As of 25 February, a change in the coverage of the virus was observed. The number of news items increased and concern gradually became part of the message. The coverage also focused on finding out who are responsible for the Spanish cases of coronavirus.

\section{Stage of Concern}

- A tourist in Adeje tested positive for coronavirus.

2020-02-25T15

- Healthcare has published several technical documents for the care and treatment of patients with coronavirus.

2020-02-25T21

- Catalonia has confirmed the fifth case of coronavirus in Spain.

2020-02-25T21

- Spain registers the first case of coronavirus in the peninsula.

2020-02-25T21

- There are two new patients with coronavirus. They had not travelled to any risk area.

2020-02-27T15

- If you suspect you may have the coronavirus, remember to call 112 and not go directly to your local health center.

2020-02-28T15

- There are already 33 cases of coronavirus in Spain. 2020-02-28T15

- Cases of coronavirus continue to increase in Spain. 2020-02-29T15

- We recall that there are already almost 120 confirmed cases of coronavirus in our country.

The next stage was depression. This stage was characterized by negative news, problems due to the lockdown, unemployment, and increases in the number of deaths. At this stage, news saturation was observed and the number of fake-news increased. The coverage started at that time a new phase, the depression stage. Most of the news included words like 'death', 'victims', 'virus', 'unstoppable', 'continue to rise'. The public perceived this change. In fact, they claimed that there was a major change in coverage. They increased the number of news items and all of them were negative. 
- The first death by the coronavirus in Spain is confirmed.

2020-03-03T21

- The fear of the coronavirus is out there.

2020-03-05T15

- Spain has more than 2,000 cases of coronavirus and 48 people have died.

2020-03-11T15

- The coronavirus vaccine will take at least a year.

- Spain is already in a state of alarm over the coronavirus crisis.

2020-03-15T15

- $\quad$ Spain has almost 1,500 new cases of coronavirus in one day, the number of infected people exceeds 9,100 , and 309 people have died.

2020-03-16T15

- The crisis of the coronavirus, with the sports competitions stopped and in many cases without possibilities of income, is forcing many teams to look for solutions to the economic losses.

2020-03-20T21

- More than a tenth of the world's coronavirus infections are in Spain.

2020-03-25T21

- They estimate that half a million companies could close down because of the coronavirus crisis.

2020-03-26T21

- $\quad$ The Ice Palace has been turned into a morgue.

2020-04-04T21

The next stage called acceptance was characterized by the news that implied a change of course. From April 8 onwards, we could observe that news with a lot of sentimental baggage was being shown. The news was centred on real families, how to face the lockdown, Internet initiatives, concerts, art, etc. The number of news focus on negative aspects began to decrease and although there was talk of unemployment, economic aid was mentioned. This stage could also be called de-escalation. Just as the pandemic was being controlled, the media was devoting more space and time to familiar content.

\section{Acceptance Stage}

- $\quad$ Every day, health workers are receiving the applause for their efforts in the fight against the coronavirus.

2020-04-11T21

- Gestures of solidarity that try to make the Holy Week of the coronavirus more comfortable.

2020-04-09T15

- Coronavirus lockdown: Living with my parents in a small apartment.

2020-04-08T15

In relation to the survey, a total of 54 respondents participated. The socio-demographic characteristics of the sample are shown in Table 6. As it has been explained along with the methodology, the distribution among groups is representative. $48.15 \%$ were men and $51.8 \%$ women. Regarding the level of education, $39.2 \%$ of subjects had university or postgraduate qualifications. Students were the largest group in terms of occupation (44.83\%). In relation to individual 
116 incomes, the highest rate was given by the group between 25,001 to 40,000 euros per year. All the participants declared to watch the TVE1 news.

\begin{tabular}{|c|c|c|c|}
\hline & Universe & Sample & \\
\hline & $47,100,396$ & 54 respondents & \\
\hline Men & $23,089,389$ & $44.4 \%$ men $(24)$ & $\begin{array}{l}\text { 12.5\% Retired } \\
20.83 \% \text { Students } \\
12.5 \% \text { Unemployment } \\
12.5 \% \text { Self-employed } \\
41.6 \% \text { employed }\end{array}$ \\
\hline Women & $24,011,006$ & $\begin{array}{l}46.3 \% \text { women } \\
(25)\end{array}$ & $\begin{array}{l}12 \% \text { retired } \\
24 \% \text { Students } \\
16 \% \text { Unemployment } \\
12 \% \text { Self-employment } \\
36 \% \text { Employed }\end{array}$ \\
\hline $\begin{array}{l}\text { Foreign } \\
\text { Population }\end{array}$ & $5,023,279$ & $\begin{array}{l}9.3 \%(5.58 \% \\
\text { women and } \\
3.72 \% \text { men) }\end{array}$ & $\begin{array}{l}\text { A woman and a man unemployed } \\
2 \text { women and one men employed }\end{array}$ \\
\hline
\end{tabular}

Source: Universe INE.

It was important for this research to know the publics' perceptions about the news coverage of the coronavirus. On the one hand, while all participants claimed that they had an excess of information, on the other hand, the majority of respondents replied that they had not perceived transparency since the beginning of this crisis. According to the frequency of the responses to the question: how do you describe your overall perception of the TVE1 news coverage of the coronavirus? A word cloud is presented in Figure 7:

Figure 7. Word cloud: Audience's perceptions

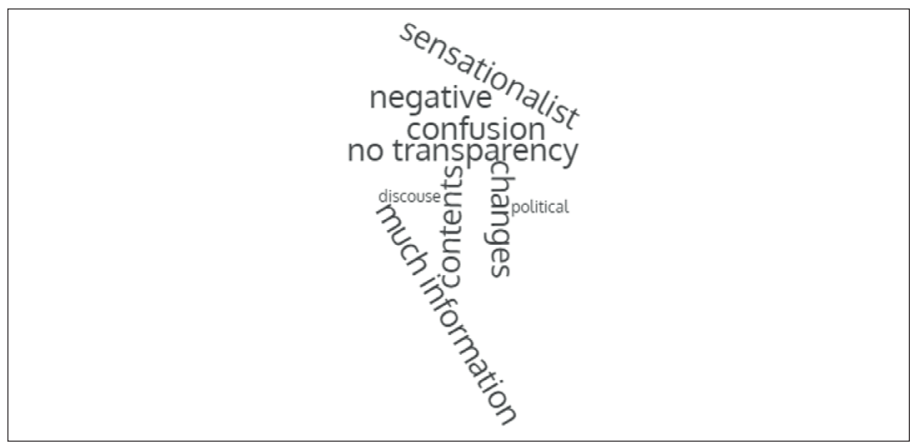


There were no differences in terms of gender although as the income level increased, the participant's language was harder and with more forceful expressions. In this regard, some quotations are presented below:

Respondent 4 (Man/ 37 years old/ Degree/Unemployed):

There was a lot of international information however until March, I was not sure if it was serious or not for Spain.

Respondent 20 (Women/ 42 years old/Degree/ Self-employed):

The content has been very changeable. The evening news and the morning news offered the same content. I would like to emphasize that I think that as time has passed the content has changed and I can now watch it with my children.

Respondent 54 (Man/ 69 years old/ Primary school/ Retired):

I don't know if I have to wear a mask or not, but I'm sure it'll rain tomorrow.

Participants affirmed that they did not perceive the reality of the situation until the beginning of March (initial stage). In fact, three of the respondents indicated that had travelled in the last week of February. The answers to these questions were included in three categories. The first was related to the lack of transparency. Participants stated that there were many changes in relation to the coronavirus coverage. Most indicated that despite numerous reports, they did not know the origin of the virus. Respondents said that if they had known about the importance of the virus, they would have taken action and behaved differently. However, respondents felt that after daily news of deaths and infections, they perceived an improvement in communication (they have perceived different stages). The second category included statements about sensationalism. In this regard, respondents felt that the content was not suitable for all audiences. Participants explained that due to the lockdown, the minors were at home and they also watched TV. Therefore, they believed that the content should have focused on more child-friendly content. The third category was related to political discourse. As explained above, TVE1 is a public media dependent on the Spanish state. Although no questions with political content were asked, most of the respondents stated that the changes in the versions about the importance of the disease were caused by political issues. Several respondents added an explanation for these changes:

Tourism is one of the main economic engines in Spain so if there had been lockdown or border closure since January, the crisis would have had more impact.

However, other respondents believed that this would have saved many lives. As for the role of the news, all respondents agreed. The media should report as transparent as possible. This work must offer an example by guaranteeing the citizens' right to accurate information on general contents. As for the last question about 
118 what could be done to improve TVE1 news, respondents offered a number of options. These are presented in Graph 3.

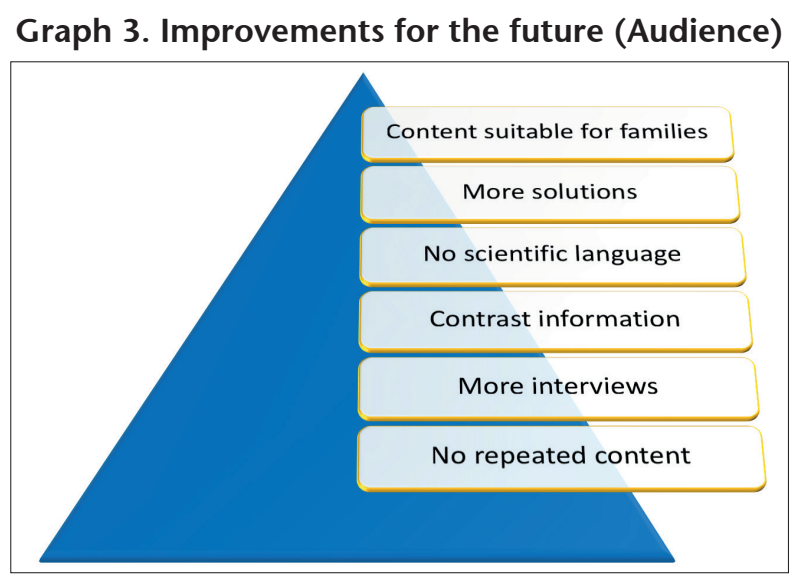

Source: The authors.

In relation to the focus group interviews, experts of recognised prestige participated divided into two groups. They authorized their participation in the interview before the research was carried out. The exhibition included two communication experts, six journalists ( 2 press, 2 radio, and 2 photographers), two medical specialists, two university professors, and a project manager. A word cloud (Figure 8) is used in to explain the results.

1. From your point of view, how has been the coverage of the coronavirus provided by the Spanish public TV (TVE1)?

Figure 8. Word cloud: Experts' perceptions

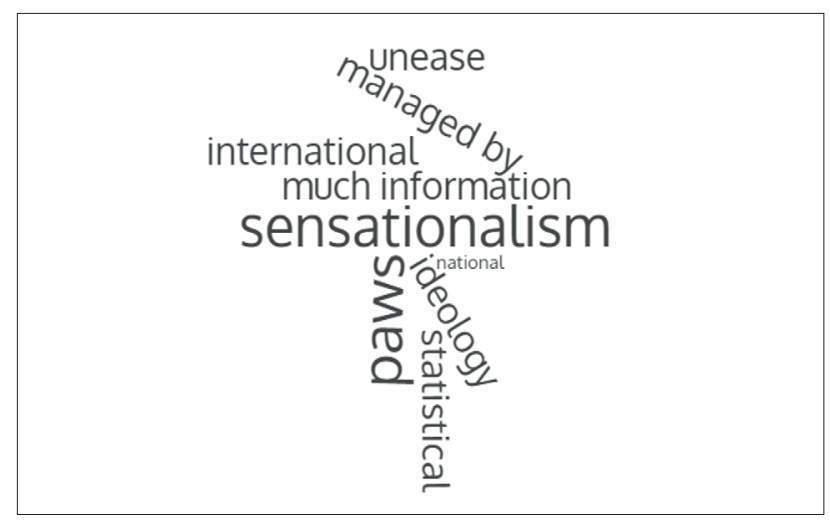

Source: The authors. 
Sensationalism was the word most mentioned by experts followed by pawns.

The comments were characterized by a feeling of protest and an evaluation of the coverage offered by the public television channel. In figure 8 , it can be seen that the agents perceived too much information and much ideological content.

Some quotations are presented:

Respondent 2 (woman/doctor):

A lot of benevolence towards the government and its policies. The news made the virus less important than it is.

Respondent 6 (woman/project manager):

The image given by the media has not been positive. The TV news looks like a government pawn. They limit themselves to transferring the information that the government wants to transfer to the citizens.

Respondent 11 (man/ journalist):

The media are highly motivated by ideological concerns. The Tve1 news, with a greater burden towards what other countries do, scare and minimize the Spanish information.

2. Looking to the future and based on the experience lived from your professional perspective, what challenges or objectives should be taken into account to improve the informative treatment of a disease such as the COVID-19?

Figure 9. Word cloud: Improvements for the future

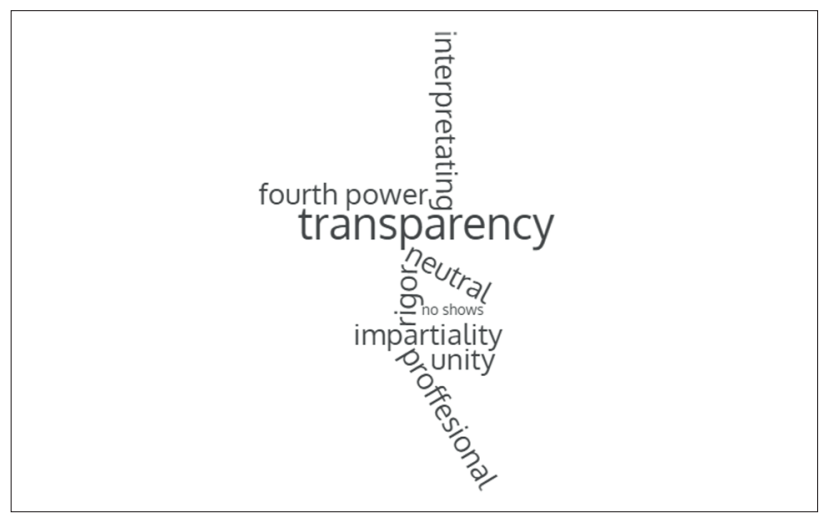

Source: The authors.

The interviewees stressed the possible improvements that the public channel should have taken into account (Figure 9). In this sense, the word most mentioned was transparency. In the opinion of most experts, the news coverage was 
politically biased. They perceived neither unity nor impartiality. In fact, some indicated that the news initially focused on international content when it should have offered more informative content. In this sense, the participants understood that the coverage of these types of topics should have been structured differently. Family content, sport at home, culture, and cooking should have been the contents present in the news. However, a high percentage stated that there was a high level of political content, especially at the beginning of the lockdown.

Respondent 6 (man/ press journalist):

The means must be protected. They should not be limited to official sources but should always take them into account, and they should be especially careful to detect fake news. Transparency.

Respondent 13 (woman/university professor):

Protection, empathy, and more creativity so that the agenda is not so homogeneous.

Respondent (man/ photographer):

Be rigorous and corroborate information before broadcasting it.

\section{DISCUSSION}

In this research, the main aim was to examine the news coverage of the coronavirus crisis. The second aim of this study was to investigate the perceptions about the coverage and if it would correspond to the focus that TVE1 news provided about this issue. The investigation has shown that the TVE1 news coverage has gone through various stages until reaching the present. When a crisis breaks out, the news multiplies, but as time goes by, that news takes a back seat. In the first phase, the media offer us little information; this increases as does our concern until suddenly we have to deal with the problem. The first mention in the subtitles was on 17 January 2020, and this referred to the origin of the virus. Initially, the news dedicated to this pandemic at a national level (Spain) was scarce compared to the international news. Both the public and experts have stated that they were not aware of the importance of the virus until March. This is related to the theory postulated by Kasperson et al. (2000). The theory affirms that when there is no direct personal experience of risk, the information can reach individuals through either the news media or personal networks, and hence public response is influenced by the volume, dramatization, and symbolic connotations of the information. There is, therefore, a relationship between public television's coverage and approach to the virus and public perceptions. The public has perceived exactly what the TVE1 has wanted them to perceive. The initial intention of the public broadcaster was unknown, but if we pay attention to the public service, the information, according to our respondents, should have been totally transparent and impar- 
tial. In this sense, although they recognize that the news broadcast focused on international news, they understand that this was due to a way of protecting the country and its tourism. A high percentage of experts indicate that in that first moment, public television tried to separate Spain from what was happening in other countries. This is what we have called the initial stage followed by a stage of concern. At this stage, the first positive cases began and with them, the first deaths were confirmed. The experts, for their part, valued the work of the media in this pandemic, although they acknowledged that they expected less political content. This was also a complaint from respondents. Everyone would have liked more familiar and child-friendly content. Experts perceived too much information. The findings of this investigation could complement future studies. It contributes in several ways to understanding media coverage and provides a basis for other content analysis. One source of weakness in this research which could have affected the findings was the sample size and the territorial limitation. Despite this, future researchers can make comparisons among countries and increase the sample. More information about the media coverage would help us to establish a greater degree of accuracy on this matter.

Eduardo Villena-Alarcón (eduardo.villena@ uma.es) is a PhD in organizational communication at the University of Malaga. Graduated in Journalism and Public Relations. He is tea-

Lidia Caballero-Galeote (lidiacaballero1985 @gmail.com) is a PhD candidate. She completed the degree in Journalism granted by the ching at the UMA with the subjects of Method and techniques of research in communication or creation of campaigns in digital environments.

University of Malaga. Her fields of research are communication, airport management and tourism.

\section{References}

Artandi, S. (1973). "Information Concepts and Their Utility". Journal of the American Society for Information Science, 24(4), pp. 242-245.

Atlani, L.; Mercier, A.; Rousseau, C.; Guyot, P., and Moatti, J. P. (2015). "Blood Libel Rebooted: Traditional Scapegoats, Online Media, and the H1N1 Epidemic". Culture, Medicine, and Psychiatry, 39(1), pp. 43-61.

Ávila, J.; Munayco, C. V.; Gómez, J.; Nunura, J., and Canahuiri, J. (2009). "Conoci- mientos y prácticas sobre la nueva Influenza A (H1N1) en trabajadores de salud y pacientes ambulatorios". Revista Peruana de Medicina Experimental y Salud Publica, 26(3), pp. 328-332.

Balabanić, I. and Benković, V. (2014). "Risk Mediatization-Case Study of Flue Pandemics Television Reporting". Medijska Istraživanja, 20(1), pp. 65.

Beaudoin, C. E. (2007). "SARS News Coverage and Its Determinants in China and 
the US". International Communication Gazette, 69(6), pp. 509-524.

Behr, R. L. and Iyengar, S. (1985). "Television News, Real-World Cues, and Changes in the Public Agenda". Public Opinion Quarterly, 49(1), pp. 38-57.

Berganza, R. (2008). "Las elecciones al Parlamento Europeo como comicios de segundo orden. Estudio de la cobertura informativa en televisión (1999-2004)". Estudios sobre el Mensaje Periodístico, 14, pp. 15-31.

Berry, T. R.; Wharf-Higgins, J., and Naylor, P. J. (2007). "SARS Wars: An Examination of the Quantity and Construction of Health Information in the News Media". Health Communication, 21(1), pp. 35-44.

Cacciatore, M. A.; Scheufele, D. A., and Iyengar, S. (2016). "The End of Framing As We Know It... and the Future of Media Effects". Mass Communication and Society, 19 (1), pp. 7-23.

Caffarel, C. (2005). "Is a Quality Television Possible? 2Comunicar. Revista Científica de Comunicación y Educación, 13(25), pp. 23-27.

Camacho, M. (2009). "La 'gripe A', en la prensa española". Revista Latina de Comunicación Social, 64. DOI: <10.4185/RLCS-64-2009865-827-843>.

Campos-Freire, F. (2009). "Modelos de televisión pública europea y latinoamericana". Chasqui. Revista Latinoamericana de Comunicación, (108), pp. 4-11.

Castro, R.; Arcos, P., and Rodríguez, A. (2009). "Sistema sanitario y triaje ante una pandemia de gripe: Un enfoque desde la salud pública". Emergencias, 21, pp. 376-381.

Cevallos, M. C. and Massarani, L. (2011). La pandemia del miedo: Telediarios y la gripe A(H1N1) en Ecuador y Brasil. Quito, Ecuador.

Chiang, W. Y. and Duann, R. F. (2007). "Conceptual Metaphors for SARS: 'War' Between Whom?" Discourse and Society, 18(5), pp. 579-602.

Chomsky, N. and Ramonet, I. (2013). "Mito 3. 'Es cierto, lo ha dicho la tele'". Presented at "11 mitos sobre la crisis", Valladolid,
Spain. Available at: <https://www.eii.uva.es/ mitos/mitos/M3.pdf>. Accessed 27 April 2020.

Covello, V. T. and Peters, R. G. (2002). "Women's Perceptions of the Risks of AgeRelated Diseases, Including Breast Cancer: Reports from a 3-Year Research Study". Health Communication, 14, pp. 377-395.

Díaz-Nosty, B. (2009). "Un sistema insostenible". Periodistas: Revista de la Federación de Asociaciones de Periodistas de España, p. 18.

-. (2017). Diez años que cambiaron los medios (2007-2017). Barcelona: Ariel y Fundación Telefónica.

Dudo, A. D.; Dahlstrom, M. F., and Brossard, D. (2007). "Reporting a Potential Pandemic: A Risk-Related Assessment of Avian Influenza Coverage in US Newspapers". Science Communication, 28(4), pp. 429-454.

Entman, R. M. (1993). "Framing: Toward Clarification of a Fractured Paradigm". Journal of Communication, 43(4), pp. 51-58.

Fogarty, A.; Imison, M.; Chapman. S., and Holding, S. (2011). "Communicating Uncertainty: How Australian Television Reported H1N1 Risk in 2009". Bio Med Central Public Health, 11, pp. 181-189.

Francescutti, P. (2010). La información científica en los telediarios españoles. Barcelona, Spain: Fundación Dr. Antonio Esteve.

—. (2013). "Epidemiología televisiva: Las patologías de los españoles según los informativos". Quaderns de la Fundació Dr. Antoni Esteve, 25, pp. 31-38.

Fuenzalida, V. (2015). “Televisión pública y cambio digital. Tecnología TV-AudienciasFormatos". Punto Cero, 20(30), pp. 31-46.

Gamo, E. and Pazos, P. (2009). "El duelo y las etapas de la vida". Revista de la Asociación Española de Neuropsiquiatría, 29(2), pp. 455469.

García, J. V. (2013). “Televisión y concentración en España: El duopolio de Mediaset y Atresmedia". Palabra Clave, 16(2), pp. 366397.

Gil, F. (2017). "Medidas, reformas y austeridad: El tratamiento de la crisis económica en 
los informativos de Televisión Española (abriljunio 2012)". Tripodos, 39, pp. 187-204.

González, H. and Portilla, I. (2014). "Tratamiento de la información medioambiental en la prensa regional y el papel de los departamentos de comunicación". Tripodos, 35, pp. 137-156.

Hilton, S. and Hunt, K. (2010). "UK Newspapers' Representations of the 2009-2010 Outbreak of Swine Flu: One Health Scare Not Over-Hyped by the Media?". Journal of Epidemiology and Community Health, 65(10), pp. 941-946.

Ho, S. (2012). "The Knowledge Gap Hypothesis in Singapore: The Roles of Socioeconomic Status, Mass Media, and Interpersonal Discussion on Public Knowledge of the H1N1 Flu Pandemic". Mass Communication and Society, (15)5, pp. 695-717.

Holland, K. and Blood, R. W. (2010). Not Just Another Flu? The Framing of Swine Flu in the Australian Press. In: ANZCA 2010: Media, Democracy and Change Conference Proceedings, Canberra, Australia.

Hu, B. and Zhang, D. (2014a). "Channel Selection and Knowledge Acquisition During the 2009 Beijing H1N1 Flu Crisis: A Media System Dependency Theory Perspective". Chinese Journal of Communication, 7(3), pp. 299-318.

-. (2014b). "Channel Selection and Knowledge Acquisition During the 2009 Beijing H1N1 Flu Crisis: A Media System Dependency Theory Perspective". Chinese Journal of Communication, 7(3), pp. 299-318.

Igartua, J. J.; Muñiz, C., and Otero, J. A. (2006). "El tratamiento informativo de la inmigración en la prensa y la televisión española. Una aproximación empírica desde la teoría del 'framing'". Global Media Journal, 3(5), pp. 1-15.

Ihekweazu, C. (2017). "Ebola in Prime Time: A Content Analysis of Sensationalism and Efficacy Information in US Nightly News Coverage of the Ebola Outbreaks". Health Communication, 32(6), pp. 741-748.
Iyengar, S. and Kinder, D. R. (1987). News that Matters: The Television and American Opinion. Chicago: Universisty Chicago Press.

Joye, S. (2010). "News Discourses on Distant Suffering: A Critical Discourse Analysis of the 2003 SARS Outbreak". Discourse and Society, 21(5), pp. 586-601.

Kasperson, R. E.; Renn, O.; Slovic, P.; Brown, H. S.; Emel, J., and Goble, R. (2000). "The Social Amplification of Risk - A Conceptual Framework". In: Slovic, P. (ed.). The Perception of Risk. Sterling, VA: Earthscan, pp. 232-245.

Larson, B. M. H.; Nerlich, B., and Wallis, P. (2005). "Metaphors and Biorisks: The War on Infectious Diseases and Invasive Species". Science Communication, 26(3), pp. 243-268.

Lippmann, W. (2003). Public Opinion. Madrid: Langre.

López-Vidales, N.; González-Aldea, P., and Medina de la Viña, E. (2011). "Jóvenes y televisión en 2010: Un cambio de hábitos". Zer, (16)30, pp. 97-113.

Lyu, H.; Chen, L.: Wang, Y., and Luo, J. (2020). "Sense and Sensibility: Characterizing Social Media Users Regarding the Use of Controversial Terms for COVID-19". arXiv preprint arXiv:2004.06307.

MacKuen, M. B.; Coombs, S. L., and Britan, G. M. (1981). More than News: Media Power in Public Affairs. Vol. 12. SAGE Publications, Incorporated.

Marín, C. (2008). Periodismo audiovisual. Información, entretenimiento y tecnologías multimedia. Barcelona: Gedisa.

Martín, V. (2007). “A Global War Against Avian Influenza". RAEL: Revista Electrónica de Lingüística Aplicada. 6, pp. 16-30.

Mateos-Pérez, J. (2009). "La información como espectáculo en el nacimiento de la televisión privada española (1990-1994)". Estudios sobre el Mensaje Periodístico, 15, pp. 315-333.

Matthes, J. (2012). "Framing Politics: An Integrative Approach". American Behavioral Scientist, 56(3), pp. 247-259. 
McCombs, M. (2006). Estableciendo la agenda. El impacto de los medios en la opinión pública y en el conocimiento. Barcelona: Paidós.

McCombs, M. and Evatt, D. (1995). "Issues and Attributes: Exploring a New Dimension in Agenda Setting". Communicación y Sociedad, 8(1), pp. 7-32.

McCombs, M. and Shaw, D. (1972). "The Agenda-Setting Function of the Mass Media". Public Opinion Quarterly, 36, pp. 176-187.

Meilán, X. (2010). Causas y consecuencias del consumo de información política en España (2000-2009) (No. 68). CIS.

Moragas, M. de and Prado, E. (2001). "Repensar la televisión pública en el contexto digital". Portal de la Comunicación, 9, pp. 1-28.

Neira, E. (2018). "Un futuro incierto para la televisión, un prometedor futuro para el contenido televisivo". Cuadernos de Periodistas: Revista de la Asociación de la Prensa de Madrid, (36), pp. 105-111.

Newman, N.; Fletcher, R.; Kalogeropoulos, A., and Nielsen, R. (2019). Reuters Institute Digital News Report 2019. Vol. 2019. Reuters Institute for the Study of Journalism.

O'Neill, D. and Harcup, T. (2009). "News Values and Selectivity". In: Wahl-Jorgensen, K. and Hanitzsch, T. (eds.). The Handbook of Journalism Studies. London: Routledge.

Perales, A. (2003). La televisión pública en la era digital. Fundación Alternativas.

Peralta, M. (2012). Teleinformativos: La noticia digital en televisión. Barcelona: UOC

Perse, E. (2001). Media Effects and Society. London: Routledge.

Puentes, I.; Campos, F., and Fernández, A. B. (2018). "La publicidad como garantía de sostenibilidad de la televisión en Europa, privada y pública". Revista Ibérica de Sistemas e Tecnologias de Informação, (16), pp. 387402.

Rando, T.A. (2015, In Press). Coping with the Sudden Death of Your Loved One: A SelfHelp Handbook for Traumatic Bereavement. Indianapolis, IN: Dog Ear Publishing.
Reig, R. "Aproximación al sistema de medios en Europa y España". In: Campos-Freire, F. (2010). El cambio mediático. Vol. 33. Spain: Comunicación Social.

Revuelta, G. (2006). "Salud y medios de comunicación en España". Gaceta Sanitaria, 20, pp. 203-208.

Rodríguez, R. F. (2011). "Esfera pública y medios de comunicación. La contribución de la media a la construcción de la ciudadanía democrática". Daimon Revista Internacional de Filosofía, pp. 79-93.

Roel, M. and Lafuente, M. (2005). "Políticas mediáticas y estrategias comunicativas: Estructura del sistema de medios en España". Sphera Pública, (5), pp. 9-15.

Ruiz, M. (2020). “¿Renacer de la salud pública en medio de la pandemia?" Revista Salud UIS, 52(2), pp. 177-177.

Sádaba, T. and Rodríguez, J. (2007). "La construcción de la agenda de los medios. El debate del Estatut en la prensa española". Ámbitos, 16, pp. 187-211.

Scheufele, D. A. and Iyengar, S. (2012). "The State of Framing Research: A Call for New Directions". In: Kenski, K.; Jamieson, K. H. (eds.). The Oxford Handbook of Political Communication Theories. New York: Oxford University Press, pp. 1-26.

Shih, T.; Brossard, D., and Wijaya, R. (2011). "News Coverage of Public Health Issues: The Role of News Sources and the Processes of News Construction". International Public Health Journal, 3(1), pp. 87-98.

Silva-Medeiros, F. N. da, and Massarani, L. (2010). "Pandemic on the Air: A Case Study on the Coverage of New Influenza $A / H 1 N 1$ by Brazilian Prime Time TV News". Journal of Science Communication, 9(3).

Sotelo, J. (2014). Medios de comunicación en España. Madrid: UMER.

Vasterman, P. L. and Ruigrok, N. (2013). "Pandemic Alarm in the Dutch Media: Media Coverage of the 2009 Influenza A (H1N1) Pandemic and the Role of the Expert Sources". European Journal of Communication, 28(4), pp. 436-453. 
Vreese, C. H. de. (2003). Framing Europe: Television News and European Integration. Amsterdam: Aksant.

Washer, P. (2004). "Representations of SARS in the British Newspapers". Social Science \& Medicine, 59(12), pp. 2561-2571.

Williams, J. T. (2009). "Metaphors of Cancer in Scientific Popularization Articles in the British Press". Discourse Studies, 11(4), pp. 465495.

Wong, L. P. and Sam, I. C. (2010). "Public Sources of Information and Information Needs for Pandemic Influenza A (H1N1)". Journal of Community Health, 35(6), pp. 676-682.

Zheng, Y.; Goh, E., and Wen, J. (2020). "The Effects of Misleading Media Reports about COVID-19 on Chinese Tourists' Mental Health: A Perspective Article". Anatolia, 1-4. DOI: $<10.1080 / 13032917.2020 .1747208>$.

Zhou, W.; Wang, A.; Xia, F.; Xiao, Y., and Tang, S. (2020). "Effects of Media Reporting on Mitigating Spread of COVID-19 in the Early Phase of the Outbreak". Mathematical Biosciences and Engineering, 17(3), pp. 2693-2707. 
